\title{
Restoration of Quaking Aspen Woodlands Invaded by Western Juniper
}

\author{
Jonathan D. Bates, ${ }^{1}$ Richard F. Miller, ${ }^{2}$ and Kirk W. Davies ${ }^{3}$ \\ Authors are ${ }^{1}$ Range Scientist, US Department of Agriculture-Agricultural Research Service, \\ Eastern Oregon Agricultural Research Center, Burns, OR 97720; ${ }^{2}$ Professor and ${ }^{3}$ Graduate Research Assistant, \\ Oregon State University, Eastern Oregon Agricultural Research Center, Burns, OR 97720.
}

\begin{abstract}
Western juniper (Juniperus occidentalis spp. occidentalis Hook.) woodlands are rapidly replacing lower elevation $(<2100 \mathrm{~m})$ quaking aspen (Populus tremuloides Michx.) stands throughout the northern Great Basin. Aspen restoration is important because these communities provide critical habitat for many wildlife species and contain a high diversity of understory shrubs and herbaceous species. We studied two juniper removal treatments to restore aspen woodlands. Treatments included cutting one-third of the juniper trees followed by early fall burning (FALL) or early spring burning (SPRING). Selective cutting of juniper was performed to increase cured surface $(0-2 \mathrm{~m})$ fuel levels to carry fire through the woodlands. We tested treatment effectiveness at removing juniper from seedlings to mature trees, measured aspen sucker recruitment, and evaluated the response to treatment of shrub and herbaceous cover and diversity. In the FALL treatment, burning eliminated all remaining juniper trees and seedlings, stimulated a 6 -fold increase in aspen suckering $\left(10000 \mathrm{ha}^{-1}\right)$, but initially resulted in a significant reduction in herbaceous cover. Spring burning removed $80 \%$ of the mature juniper trees that remained after cutting. However, $50 \%$ of juniper juveniles survived the SPRING treatment, which will permit juniper to redominate these stands in less than 80 years. Aspen suckering in the SPRING increased only 2.5 -fold to 5300 stems ha $^{-1}$ by the third year after fire. In the SPRING, herbaceous cover increased $330 \%$ and the number of species observed doubled by the third year after fire. If the management objective is to eliminate western juniper with minimal cutting and stimulate greater aspen suckering, we recommend that woodlands be burned in the fall. If the objective is to maintain shrub and herbaceous cover and moderately increase aspen suckering, spring burning is recommended. With spring burning it appears follow-up management will be necessary to remove juniper that are missed in initial treatments.
\end{abstract}

\section{Resumen}

Los bosques de "Western juniper" (Juniperus occidentalis spp. occidentalis Hook.) están reemplazando rápidamente a las poblaciones de "Quaking aspen" (Populus tremuloides Michx.) de baja elevación $(<2100 \mathrm{~m}$ ) a lo largo de la Gran Cuenca del norte. La restauración del "Quaking aspen" es importante porque estas comunidades proveen un hábitat critico para muchas especies de fauna silvestre y en su estrato bajo tienen una gran diversidad de especies arbustivas y herbáceas. Estudiamos dos tratamientos de remoción del "Western juniper" para restaurar los bosques de "Aspen". Los tratamientos incluyeron el corte de $1 / 3$ de los árboles de "Western juniper" seguido por una quema a inicio de otoño (OTOÑO) o una quema a inicio de primavera (PRIMAVERA). El corte selectivo del "Western juniper" se realizó para incrementar los niveles de combustible superficial curado (0-2 m) para conducir el fuego a través de los bosques. Probamos la efectividad de los tratamientos para remover el "Western juniper" desde plántulas hasta árboles maduros, midiendo el establecimiento de retoños de "Aspen" y evaluamos la respuesta de la cobertura y diversidad de especies arbustivas y herbáceas a los tratamientos. En el tratamiento de OTOÑO, la quema eliminó todos los árboles y plántulas remanentes de "Western juniper" y estimuló un aumento de 6 veces de los retoños de "Aspen" $\left(10000 \mathrm{ha}^{-1}\right)$, pero inicialmente resultó en una reducción severa de la cobertura herbácea. La quema en primavera removió el $80 \%$ de los árboles maduros de "Western juniper" que permanecieron después del corte. Sin embargo, 50\% de los "Western juniper" juveniles sobrevivieron al tratamiento de PRIMAVERA, lo cual permitirá que el "Western juniper" vuelva a dominar estas poblaciones en menos de 80 años. Al tercer año después del fuego, la producción de retoños de "Aspen" en el tratamiento de PRIMAVERA se incrementó solo 2.5 veces, a 5300 tallos ha ${ }^{-1}$. En el tratamiento de PRIMAVERA la cobertura de herbáceas aumentó en $330 \%$ y el número de especies observadas se duplicó para el tercer año después del fuego. Si el objetivo de manejo es eliminar el "Western juniper" con un corte mínimo y estimular el un gran rebrote del "Aspen”, nosotros recomendamos que los bosques se quemen en otoño. Si el objetivo es mantener la cobertura de arbustivas y herbáceas e incrementar moderadamente el rebrote de "Aspen" se recomienda la quema en primavera. Con la quema de primavera parece que es necesario un manejo complementario para remover los "Western juniper" que se escaparon en los tratamientos iniciales.

Key Words: fire, disturbance, diversity, Juniperus occidentalis, Populus tremuloides, succession

The Eastern Oregon Agricultural Research Center is jointly funded by the USDA Agricultural Research Service and Oregon State Agricultural Experiment Station.

Correspondence: Jon Bates, United States Department of Agriculture, Agricultural Research Service, Eastern Oregon Agricultural Research Center, 67826-A Hwy 205, Burns, OR 97720. Email: jon.bates@oregonstate.edu

Manuscript received 12 December 2004; manuscript accepted 13 October 2005. 


\section{INTRODUCTION}

Quaking aspen (Populus tremuloides Michx.) woodlands are important plant communities in the interior mountains of the western United States. Though occupying relatively small areas within vast landscapes, aspen woodlands provide essential habitat for many wildlife species (Maser et al. 1984; DeByle 1985) and contain a high diversity of understory shrub and herbaceous species (Bartos and Mueggler 1981, 1982). Aspen is estimated to occupy 2.9 million ha in the western United States (including Northern New Mexico and Arizona, Utah, Colorado, Wyoming, Montana, South Dakota, Idaho, Nevada, and eastern Oregon; Brown 1985). However, aspen woodlands have declined the last century as a result of encroachment by conifers (Schier 1975; Gruell 1979; Miller and Rose 1995; Bartos and Campbell 1998) and excessive browsing by native ungulates (Bartos et al. 1994; Kay 1995). Conifer encroachment has been attributed to the disruption of historic fire cycles during the last 120 years (Olmsted 1979; DeByle 1980; Brown 1985). The aboveground stem of this clonal species is relatively short lived; thus, aspen commonly requires fire to eliminate competing vegetation and stimulate root sprouting to regenerate stands (Brown 1985).

The decline of aspen has been well documented in the Rocky Mountain states (Bartos and Campbell 1998). Only recently has aspen decline been described for the Great Basin (Miller and Rose 1995; Wall et al. 2001). An extensive survey of aspen in the northern Great Basin reported significant encroachment of western juniper (Juniperus occidentalis spp. occidentalis Hook.) into aspen woodlands below $2150 \mathrm{~m}$ (Wall et al. 2001). Western juniper woodlands have increased 9 -fold during the last 150 years and are estimated to occupy 4 million ha in eastern Oregon, southwest Idaho, and along the northern border of California and Nevada (Miller et al. 2005).

The purpose of this study was to evaluate two juniper removal treatments to restore aspen stands in the northern Great Basin using combinations of selective cutting and seasonally applied fire. Our treatments involved cutting onethird of mature juniper trees followed by an early fall burning (FALL) or an early spring burning (SPRING). Selective cutting of juniper was conducted to increase cured surface fuel levels to carry fire through the aspen stands, kill remaining juniper, and stimulate aspen regeneration. This method of juniper control has become a common land management practice in southeastern Oregon and northern California. The objectives of our study were to 1) test the effectiveness of treatments at removing juniper from seedlings to mature trees, 2) measure treatment effectiveness at stimulating aspen recruitment, and 3) evaluate the response of shrub and herbaceous understories to treatment.

Disturbances in plant communities often vary in severity, which influences vegetation mortality, response, and successional dynamics (Pickett and White 1985). In our study, we anticipated that the seasonal burn treatments would result in different levels of fire severity, thus influencing the degree of juniper control, the level of aspen regeneration, and the composition of understory succession. Seasonal burning produces variable fire severities and intensities, which influence plant composition and successional response (Sparks et al. 1998; Howe 2000; Engle and Bidwell 2001). Aspen community response to fire is influenced by the level of fire severity (Bartos and Mueggler 1980, 1982). We anticipated that fall fire would be more intense because of drier fuel conditions and would thus produce a more severe fire than the spring fire, and result in complete stand replacement. Thus, we hypothesized the FALL treatment would be more effective at removing juniper trees and stimulating greater aspen recruitment than the SPRING treatment. Because of the anticipated lower fire severity in the SPRING treatment, shrub and herbaceous species were expected to remain largely unaffected. We predicted that understory cover and richness would be greater in the SPRING compared with the FALL treatment within the first 3 growing seasons following treatment.

\section{MATERIALS AND METHODS}

\section{Site Description}

Our study site was located in Kiger Creek Canyon on Steens Mountain, southeastern Oregon. Aspen stands were scattered along toe slopes above the riparian zone and in drainages and seeps in adjacent uplands from 1645 to $1830 \mathrm{~m}$ elevation. Individual stands were small, averaging 0.6 ha in area. The surrounding upland communities consisted of mountain big sagebrush (Artemisia tridentata spp. vaseyana [Nutt.] Beetle $\&$ A. Young) grasslands and mountain mahogany (Cercocarpus ledifolius [Nutt.] Torr. \& Gray) thickets.

The aspen stands have been reduced in area and tree density and were dominated by western juniper (Table 1). Juniper began establishing in these stands in the 1860s (Miller and Bates 2001). Juniper that established prior to 1940 dominated the overstory. Since the 1940s, juniper in the subcanopy increased significantly. Juniper woodlands were rated as being in late to closed successional phases according to criteria developed by Miller et al. (2000). Using criteria developed by Bartos and Campbell (1998) the aspen stands were identified as being in decline.

There was a high diversity of forbs and grasses; 73 species were identified. Western snowberry (Symphoricarpus oreophilus Gray) and wax currant (Ribes cereum Dougl.) were the most common shrub species. Other shrubs that were minor components of the shrub layer included elderberry (Sambucus racemosa L.), gray and green rabbitbrush (Chrysothamnus nauseosus [Pall.] Britt. and Chrysothamnus viscidiflorus [Hook.] Nutt.), golden currant (Ribes aureum Pursh.), Wood's rose (Rosa woodsii Lindl.), Oregon grape (Berberis repens Lindl.), and western serviceberry (Amelanchier alnifolia Nutt.).

Table 1. Pretreatment vegetation characteristics (cover and density) of aspen communities in Kiger Canyon, Steens Mountain, Oregon. Values represent means \pm 1 standard error.

\begin{tabular}{lcccc}
\hline & & \multicolumn{3}{c}{ Density } \\
\cline { 3 - 5 } & & \multicolumn{3}{c}{ Subcanopy $^{2}$} \\
Vegetation type & Cover (\%) & Dominant $^{1}$ & $\left(\right.$ No. ha $\left.^{-1}\right)$ & Juveniles $^{3}$ \\
\hline Aspen & $19.2 \pm 1.9^{4}$ & $21 \pm 6$ & $542 \pm 99$ & $1906 \pm 235$ \\
Juniper & $41.5 \pm 2.0^{4}$ & $77 \pm 9$ & $238 \pm 36$ & $1191 \pm 92$ \\
Herbaceous & $15.2 \pm 0.9$ & - & - & - \\
\hline
\end{tabular}

${ }^{1}$ Trees $>75 \%$ height of tallest individuals in plot.

${ }^{2}$ Trees $<75 \%$ of canopy dominant height.

${ }^{3}$ Juniper trees $<1 \mathrm{~m}$ in height and aspen suckers $<2 \mathrm{~m}$ in height.

${ }^{4}$ Cover is total for all size classes (aspen, juniper). 


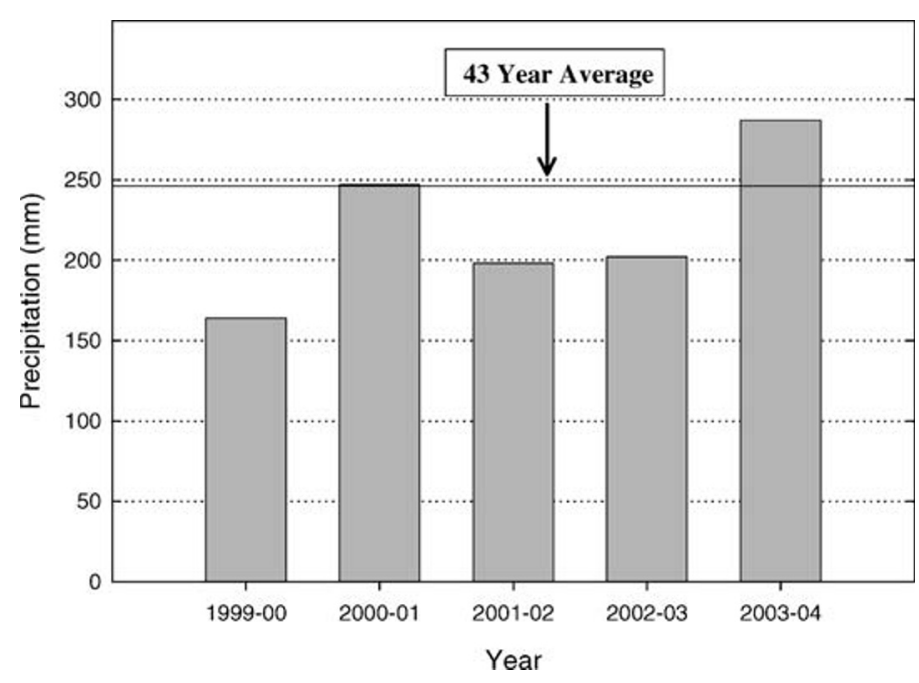

Figure 1. Annual precipitation (in millimeters), 1999-2004, and the long-term average (43 years) at the Malheur National Wildlife Refuge weather station (1250 m), located $38 \mathrm{~km}$ northwest of the study site.

The closest weather station, located at the Malheur National Wildlife Refuge (1 $250 \mathrm{~m}$ elevation), is $38 \mathrm{~km}$ northwest of the site. Annual precipitation (from 1 October to 30 September) at the refuge has averaged $248 \mathrm{~mm}$ during the last 43 years (Fig. 1). Precipitation at the refuge probably underestimated what was received at our study area, which is $400-600 \mathrm{~m}$ higher in elevation. Most aspen areas in the western United States receive at least $380 \mathrm{~mm}$ of precipitation annually or have access to elevated water tables (Jones and DeByle 1985a). We have provided precipitation data from the refuge only to serve as an indication of annual precipitation trends during the study period. Precipitation was below average during the first 2 years post-treatment (2001-2004; Fig. 1).

\section{Study Design and Burn Applications}

The study was designed as a randomized block (Peterson 1985). Ten 0.60-ha blocks were established in aspen stands in May 2000. A block consisted of three treatment plots: an untreated control (CONTROL), juniper cutting followed by fall prescribed fire (FALL), and juniper cutting followed by early spring prescribed fire (SPRING). Plots were about 0.13 ha in size. Livestock were excluded from the area during the experiment.

Cutting involved felling one-third of the mature (dominant and subcanopy) juniper trees, evenly distributed through the stand. Junipers were cut in winter and spring 2001 and allowed to dry during the summer. An average of 106 (range 55-175) juniper trees (dominant and subcanopy trees) were cut in each plot. The cut trees served to increase the level of cured surface $(0-2 \mathrm{~m})$ fuels to carry fire through the stand. Fall burning was applied in the canyon in October 2001 by personnel of the Bureau of Land Management (BLM), Burns District, Oregon. The prescribed fire technique used was a spot head fire using helicopter-dropped, delayed-action ignition devices (DIADS). DIADS were chemically injected ping-pong balls. To prevent dropping of ignition devices in CONTROL and SPRING treatments, these areas were marked with strips of butcher paper, located $100-200 \mathrm{~m}$ from plots requiring protection. Spring burning was a head fire, applied in April 2002 using drip
Table 2. Weather and fuel moisture conditions for SPRING and FALL prescribed fire treatments of aspen communities, Steens Mountain, Oregon.

\begin{tabular}{lcc}
\hline Condition & FALL & SPRING \\
\hline Weather & & \\
$\quad$ Air temperature $\left({ }^{\circ} \mathrm{C}\right)$ & $14-18$ & $12-18$ \\
Relative humidity $(\%)$ & $27-42$ & $42-52$ \\
Wind speed $(\mathrm{kph})$ & $15-20$ & $6-8$ \\
Fuel moisture content $(\%)$ & & \\
Soil water $(0-10 \mathrm{~cm})$ & 11 & 35 \\
Ground litter & 6 & 130 \\
Herbaceous fuels & 7 & 185 \\
10-h fuels & 10 & 18 \\
\hline
\end{tabular}

torches with a 50:50 mixture of unleaded gas and diesel. Fuel continuity of the cut junipers was sufficient for fire to carry with minimal re-ignition.

Fire severity was estimated by adapting severity categories developed by Bartos et al. (1994) for evaluating plant community response to fire. The severity categories were light $(1 \%-20 \%$ of litter and understory consumed, needles and small branches of downed juniper consumed, and only a few mature aspen/juniper killed), moderate $(21 \%-80 \%$ of litter and understory consumed, large branches and trunks remained on downed juniper, and $<90 \%$ of adult aspen/juniper killed), and high $(81 \%-100 \%$ of litter and understory consumed, only trunks of downed juniper remaining, and $>90 \%$ of adult aspen/juniper killed).

Gravimetric soil water $(0-10 \mathrm{~cm})$ and fuel moisture (herbaceous fine fuels, ground litter, and 10-hour fuels) were measured the day prior to fire application for the FALL treatment and on the day of fire application for the SPRING treatment (Table 2). Fuel moisture and soil water were determined by drying at $100^{\circ} \mathrm{C}$ to a constant weight. Weather data (relative humidity, wind speed, temperature) were recorded on the day of fire applications. Weather conditions were typical for fall and spring burn prescriptions applied in the northern Great Basin.

\section{Vegetation Measurements}

Pretreatment measurements were made in July 2000. Posttreatment measurements were made in July 2002, 2003, and 2004. In each plot, 3 permanent $40-\mathrm{m}$ transects were established with transects spaced 10-m apart. Juniper was separated into three size classes: dominants (trees $\geq 75 \%$ of stand height), subcanopy ( $\geq 1$-m height up to $75 \%$ of stand height), and juveniles ( $<1 \mathrm{~m}$ in height). Aspen was also separated into three classes: dominants, subcanopy, and suckers $(<2 \mathrm{~m}$ in height). Tree and shrub cover were estimated by line intercept along the 40-m transects. Densities of dominant and subcanopy trees were estimated by counting all rooted individuals along 3 , $6 \times 40 \mathrm{~m}$ belt transects. Densities of aspen suckers and juvenile junipers were estimated by counting all rooted individuals along $3,2 \times 40 \mathrm{~m}$ belt transects. Terminal utilization of aspen suckers was counted in the $2 \times 40 \mathrm{~m}$ belt transects.

Understory canopy cover was sampled inside $0.2 \mathrm{~m}^{2}$ frames $(0.4 \times 0.5 \mathrm{~m})$. Frames were placed every $2 \mathrm{~m}$ along transect 


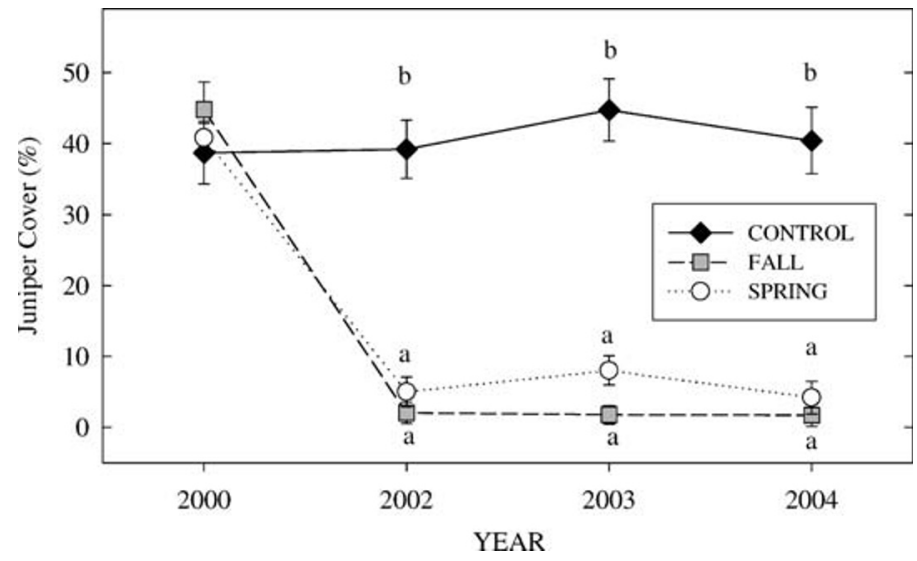

Figure 2. Western juniper cover (percent) among the three treatments. Values represent means \pm 1 standard error. Different lowercase letters indicate significant differences $(P<0.05)$ among the treatments within year.

lines. Cover was visually estimated by plant functional group (perennial grass, annual grass, perennial forb and ferns, annual and biennial forb), bare ground, rock, and litter. A species list (richness) was compiled for each treatment plot using nomenclature from Hitchcock and Cronquist (1987).

\section{Statistical Analysis}

Although the aspen plots were treated individually, the study was included in a prescribed fire project encompassing 2850 ha in Kiger Canyon and adjacent uplands. Because of the fuel characteristics in the canyon, weather, and method of ignition, there was the potential that some SPRING and CONTROL plots would be inadvertently burned with the fall prescribed fire. Of the 10 blocks, SPRING and CONTROL plots in 5 of the blocks were entirely or partially disturbed in the fall burn treatment. A repeated-measures analysis of variance for a randomized block design $(\mathrm{df}=4)$ was used to assess the influence of year $(\mathrm{df}=3)$, treatment $(\mathrm{df}=2)$, and the year by treatment interaction $(\mathrm{df}=6$, error $\mathrm{df}=44)$ on tree (juniper and aspen) density and cover, shrub cover, herbaceous cover (total and functional group), species richness, bare ground, and litter. Because of the strong year effect, years were analyzed separately to simplify presentation of the results and to assist in explaining interactions. Data were tested for normality using the SAS univariate procedure (SAS 2002). Data not normally distributed were arc sinesquare root transformed to stabilize variance. Back-transformed means are reported in the results. Statistical significance of all tests was set at $P<0.05$. Treatment means were separated using Fisher's protected least squares difference (LSD) procedure.

\section{RESULTS}

\section{Fire Severity}

Weather and fuel moisture during the fire applications were different between the treatments. Humidity was lower and wind speed greater for the FALL vs. SPRING treatment (Table 2). Soil and fuel moisture were higher at the time of the burn in the SPRING treatment. The greater litter and fuel moisture content, and higher relative humidity in the SPRING treat-

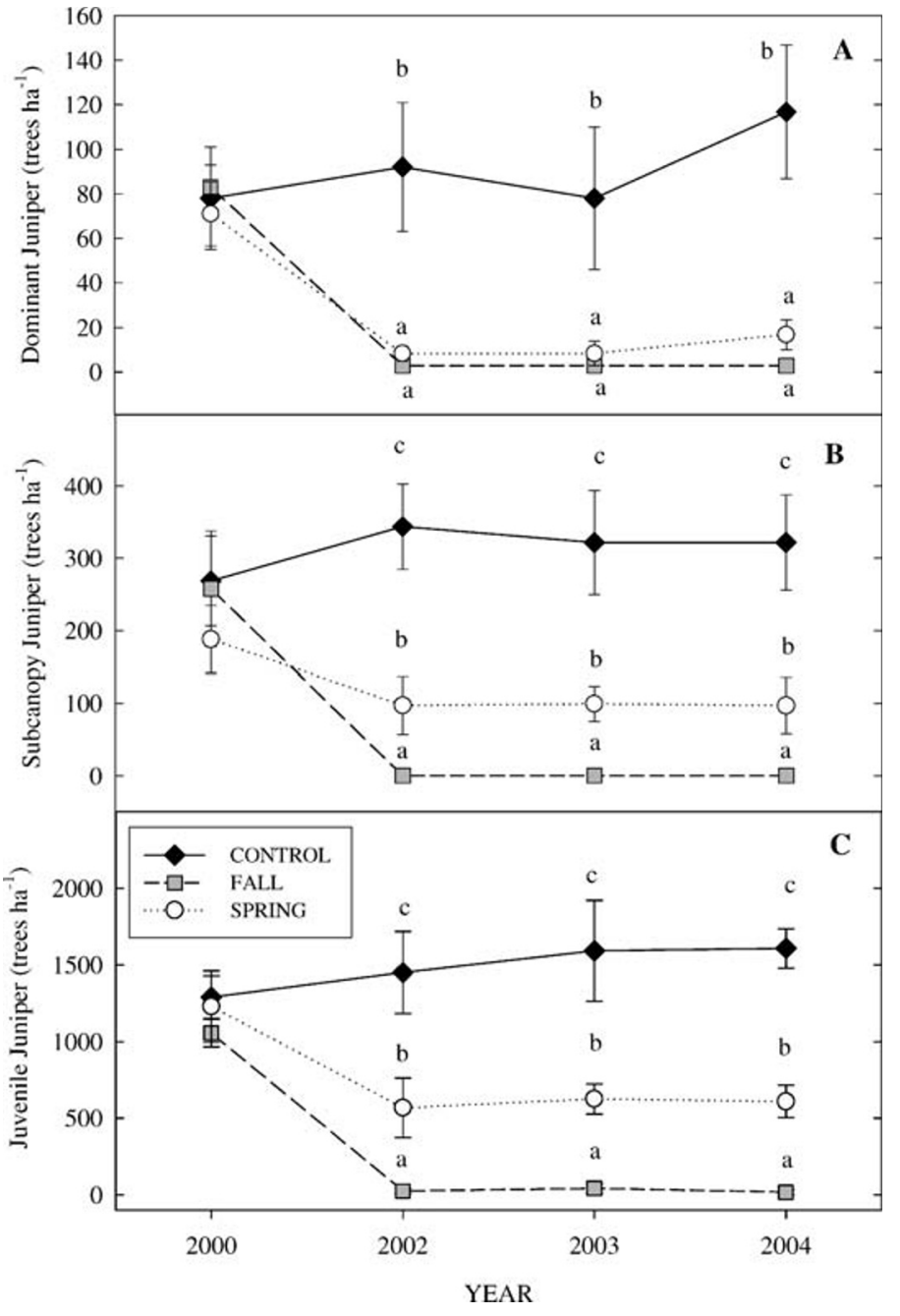

Figure 3. Western juniper tree densities (No. per hectare) among the three treatments for: A, juniper dominants; B, subcanopy juniper; and C, juniper seedlings. Values represent means \pm 1 standard error. Different lowercase letters indicate significant differences $(P<0.05)$ among the treatments within year.

ment resulted in a less severe fire. In the SPRING treatment, consumption of litter and the understory was less than $1 \%$. Suspended needles and small branches of downed juniper were consumed, but needles contacting the ground, large branches, and trunks remained. About $55 \%$ of remaining live juniper and almost $76 \%$ of the adult aspen stems were killed by the fire treatment. Fire severity in the SPRING treatment was rated as having no impact on the understory and was rated as having moderate impact on live trees. In the FALL treatment, all downed juniper material, with the exception of the trunks, was fully consumed. Litter and understory consumption was $>95 \%$, and mature juniper and aspen kill were $99 \%$ and $100 \%$, respectively. Fire severity in the FALL treatment was high.

\section{Juniper Control}

The juniper cutting and prescribed fire treatments resulted in significant reductions in juniper cover (Fig. 2) and density (Fig. 3A-3C) in both SPRING and FALL treatments compared with controls. Treatment by year interactions were significant for cover and density of all juniper size classes (Table 3). Juniper 
Table 3. $P$ values for juniper, aspen, and understory response variables for main effects (year, treatment) and the interaction (year $\times$ treatment) for aspen communities on Steens Mountain, Oregon. Values are significant when $P<0.05$.

\begin{tabular}{|c|c|c|c|}
\hline Response variable & Year & Treatment & Year $\times$ treatment \\
\hline \multicolumn{4}{|l|}{ Juniper cover } \\
\hline Total & $<0.0001$ & $<0.0001$ & $<0.0001$ \\
\hline Dominant & $<0.0001$ & $<0.0001$ & 0.0486 \\
\hline Subcanopy & 0.0056 & $<0.0001$ & 0.0017 \\
\hline Juvenile & 0.0001 & $<0.4694$ & 0.0035 \\
\hline \multicolumn{4}{|l|}{ Juniper density } \\
\hline Dominant & 0.0064 & $<0.0001$ & 0.0366 \\
\hline Subcanopy & 0.0381 & $<0.0001$ & 0.0208 \\
\hline Juvenile & 0.0022 & $<0.0001$ & 0.0040 \\
\hline \multicolumn{4}{|l|}{ Aspen cover } \\
\hline Total & 0.1155 & 0.0048 & 0.0319 \\
\hline Dominant/subcanopy & 0.3567 & 0.0005 & 0.4668 \\
\hline Sucker & 0.0014 & $<0.0001$ & 0.0028 \\
\hline \multicolumn{4}{|l|}{ Aspen density } \\
\hline Dominant/subcanopy & 0.1452 & $<0.0015$ & 0.5014 \\
\hline Sucker & $<0.0001$ & $<0.0001$ & $<0.0001$ \\
\hline \multicolumn{4}{|l|}{ Understory } \\
\hline Total herbaceous cover & $<0.0001$ & $<0.0001$ & $<0.0001$ \\
\hline Perennial grass cover & $<0.0001$ & $<0.0001$ & $<0.0001$ \\
\hline Annual grass cover & 0.1678 & 0.1078 & 0.0646 \\
\hline Perennial forb cover & 0.0015 & 0.0003 & 0.2503 \\
\hline Annual forb cover & $<0.0001$ & $<0.0001$ & $<0.0001$ \\
\hline Shrub cover & 0.8823 & $<0.0001$ & 0.8156 \\
\hline Species richness & 0.0456 & 0.0105 & 0.0245 \\
\hline
\end{tabular}

cover and density did not differ among treatments prior to cutting and burning, after which cover and density were greater in the CONTROL. In the FALL treatment, all dominant and subcanopy juniper were killed (Figs. 3A and 3B) and the density of juvenile juniper was reduced by $99 \%$ (Fig. 3C). In the SPRING treatment, juniper cover was reduced by $90 \%$ the first year after treatment. The SPRING treatment was effective at removing juniper dominants $(80 \%$ removed), but was less effective at removing subcanopy trees and juveniles. In the SPRING treatment, about $33 \%$ of the subcanopy juniper and $45 \%$ of the juveniles survived the cut and burn treatment (Fig. 3B and 3C).

\section{Aspen Response}

Treatment by year interaction was significant for total aspen cover, aspen sucker cover, and sucker density (Table 3). In the FALL treatment, all adult aspen were killed by the fire (Fig. $4 \mathrm{~A})$. In the SPRING treatment, about $24 \%$ of adult aspen survived the burn. Aspen sucker density was significantly greater in the FALL treatment, in all post-treatment years, than in the SPRING and CONTROL treatments (Fig. 4B). In 2003 and 2004, aspen sucker density was two times greater in the FALL than the SPRING treatment.

The response to treatment can be further characterized by aspen cover dynamics. The first growing season after treatment,

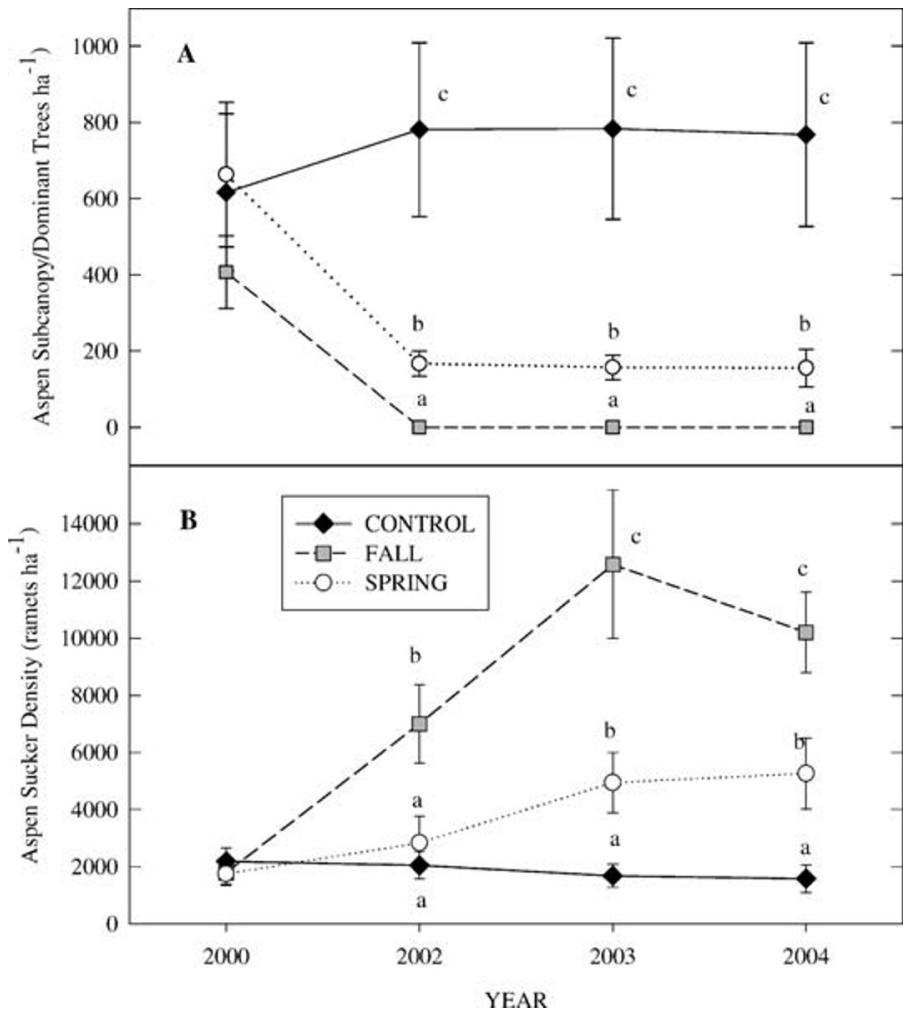

Figure 4. Aspen size class densities (No. per hectare) among the three treatments for $\mathbf{A}$, aspen subcanopy and dominants; and $\mathbf{B}$, sucker densities. Values represent means \pm 1 standard error. Different lowercase letters indicate significant differences $(P<0.05)$ among treatments within year.

total aspen cover in SPRING and FALL treatments declined by $70 \%$ from preburn levels (Fig. 5A). Aspen cover recovered quickly in the FALL treatment, and by the second year posttreatment did not differ from the CONTROL. In the FALL treatment, aspen cover in 2002-2004 was entirely composed of new aspen suckers (Fig. 5B). Total aspen cover in the SPRING treatment recovered more slowly and was less than the CONTROL and FALL treatments in 2003 and 2004. In the SPRING treatment, about $60 \%$ of the cover was composed of aspen suckers in 2004 (Fig. 5B); the balance comprised dominant and subcanopy trees (Fig. 5C). No browsing of aspen suckers was documented in the study.

\section{Ground Cover Dynamics}

In the FALL treatment, the complete consumption of fine fuels and ground surface litter increased levels of bare ground compared with the other treatments (Fig. 6A). Bare ground was three times greater in the FALL compared with CONTROL and SPRING treatments. Remaining litter in the FALL treatment primarily consisted of charred wood from cut juniper (Fig. 6B). There was little consumption of surface litter in the SPRING treatment. As a result, CONTROL and SPRING treatments had greater litter cover than the FALL treatment.

In the SPRING treatment, herbaceous mortality appeared to be low, and as a result, the understory responded quickly to partial removal of overstory interference. Herbaceous cover in the SPRING was greater than in the FALL in all post-treatment years and exceeded the CONTROL in 2003 and 2004 (Fig. 


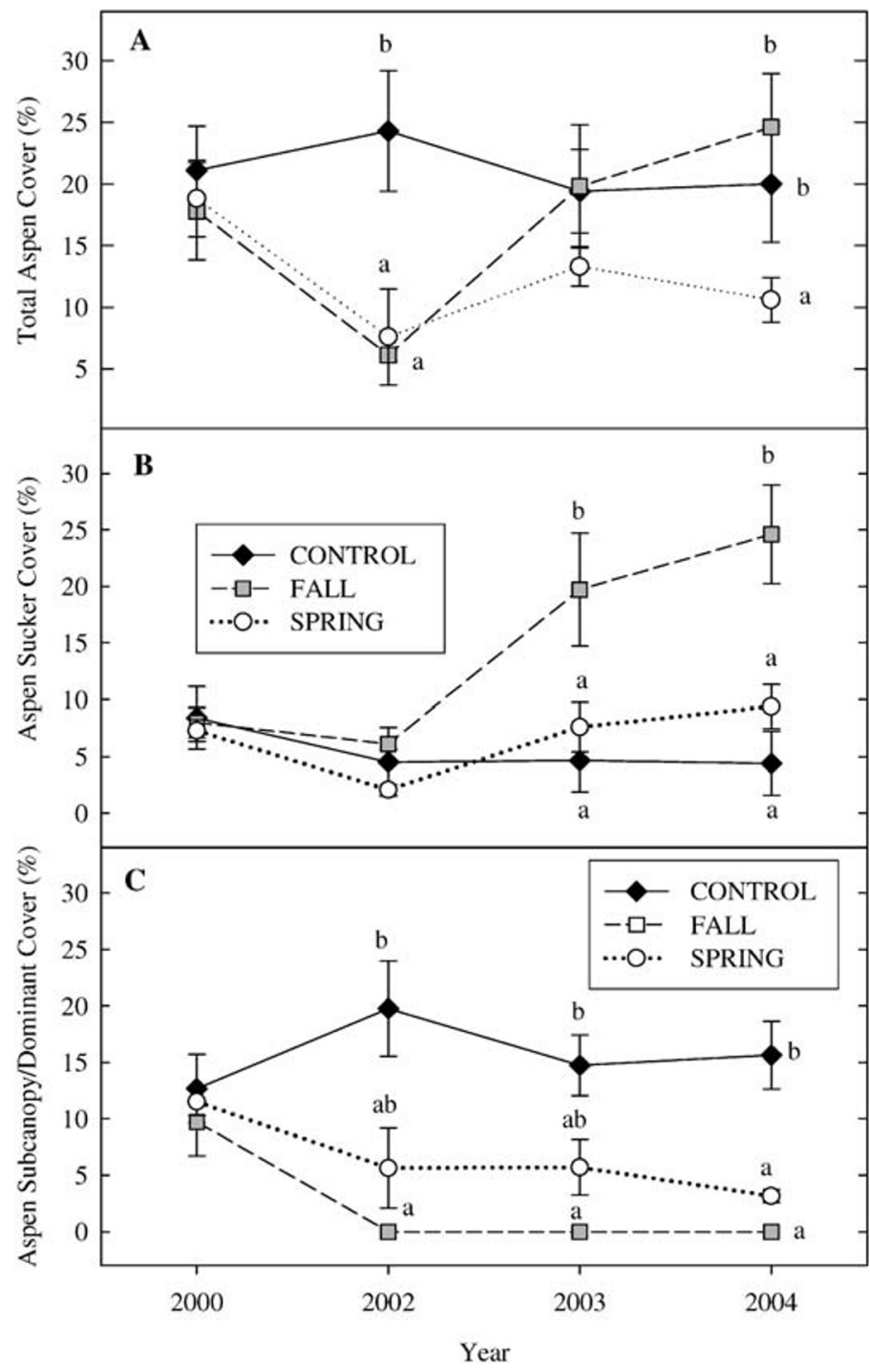

Figure 5. Aspen canopy cover values (percent) for A, total aspen; B, aspen suckers; and C, subcanopy and dominants aspen. Values represent means \pm 1 standard error. Different lowercase letters indicate significant differences $(P<0.05)$ among treatments within year.

6C). In the FALL treatment, we observed greater mortality of understory plants; thus, herbaceous response to treatment was slower than in the SPRING treatment.

Treatment and year interactions were observed for total herbaceous cover, cover of perennial grasses and annual forbs, and species richness (Table 3). In the SPRING treatment, cover of perennial grasses increased across years and dominated herbaceous response to treatment (Fig. 7A). By the third growing season after the fire, perennial grass cover was four times greater in the SPRING than in CONTROL and FALL treatments. Perennial grasses in the FALL treatment required 3 growing seasons to return to pretreatment levels. Perennial grass and perennial forb cover in the FALL treatment did not differ from the CONTROL in all post-treatment years. In the SPRING treatment, perennial forb cover increased the first growing season after treatment and was greater than the CONTROL in all post-treatment years (Fig. 7B). The FALL application did result in a significant increase in annual forb cover compared

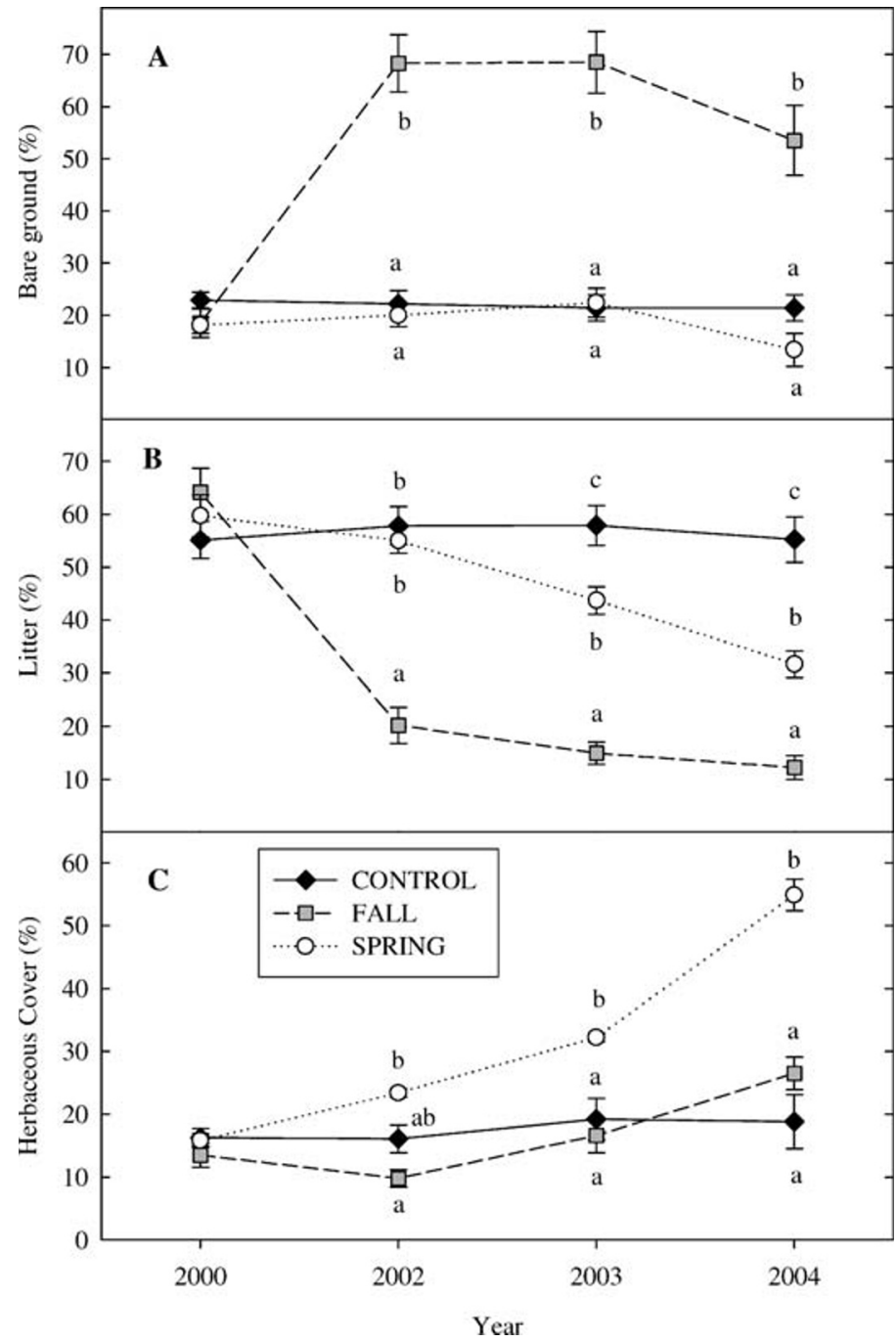

Figure 6. Understory ground cover (percent) among the three treatments for A, bare ground; B, litter; and C, herbaceous plants. Values represent means \pm 1 standard error. Different lowercase letters indicate significant differences $(P<0.05)$ among the treatments within year for each response variable.

with the other two treatments (Fig. 7C). In the FALL treatment, native perennial and annual forbs were the main component of the understory the first 2 years post-treatment. Species richness was greater in the SPRING than in the other treatments (Fig. 7D). The higher richness in the SPRING treatment resulted from an increase in perennial forb species (Table 4).

Shrub cover initially was reduced after the fire in the FALL treatment (Fig 8). However, shrub cover in the FALL treatment was not different from the other treatments by 2004. Shrub cover did not change in the SPRING treatment, and did not surpass cover in the CONTROL.

\section{DISCUSSION}

The results of this study demonstrated that succession in aspen communities can be manipulated by applying fire at different seasons. The differences in the severity of the FALL and SPRING fire treatments yielded variations in both the level 


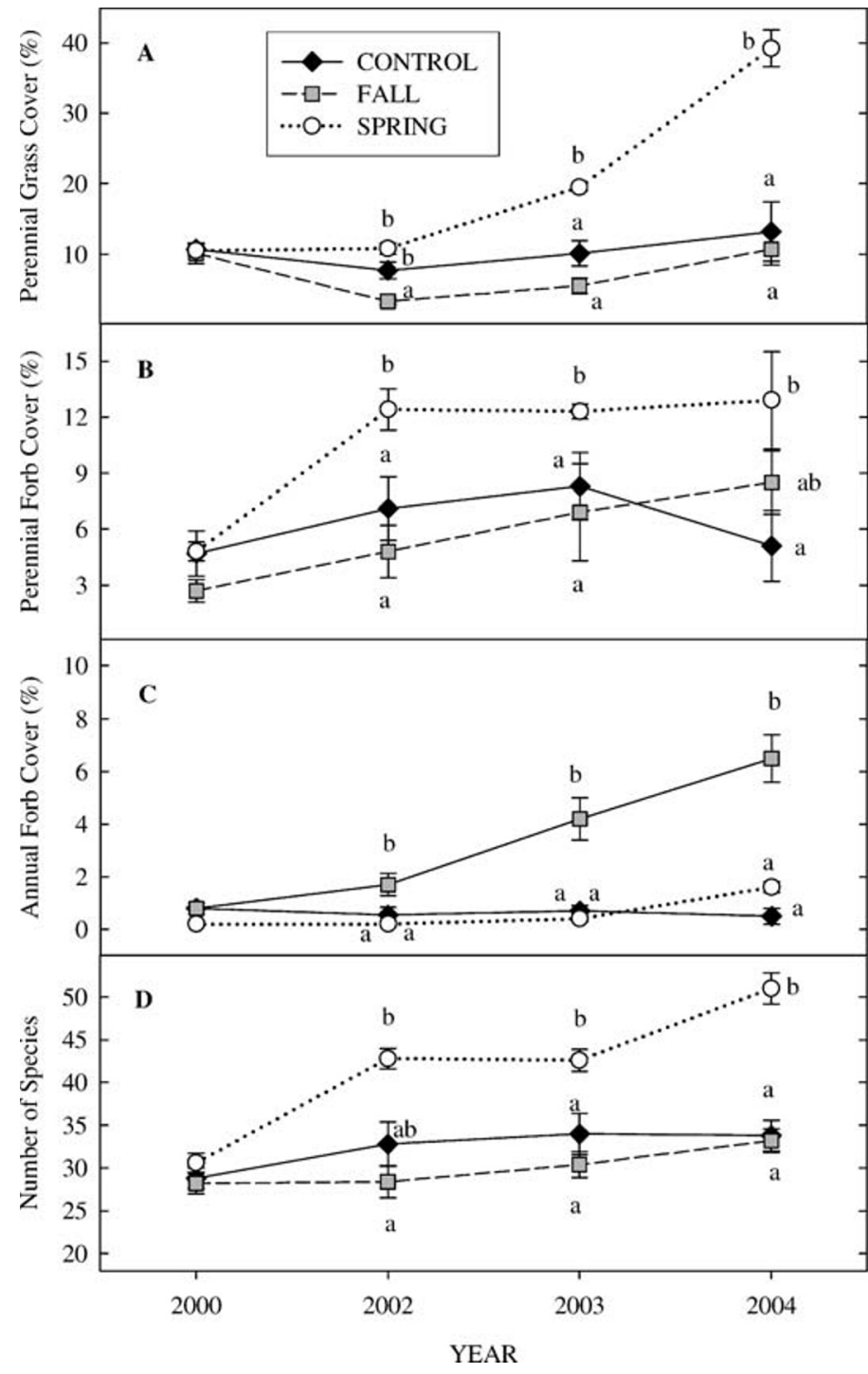

Figure 7. Canopy cover (percent) for herbaceous functional groups and herbaceous species numbers among the three treatments for $\mathbf{A}$, perennial grasses; B, perennial forbs; C, annual forbs; and D, number of species. Values represent means \pm 1 standard error. Different lowercase letters indicate significant differences $(P<0.05)$ among the treatments within year for each response variable.

and composition of vegetative response. Plant community response to disturbance can partly be explained by life history characteristics of species present prior to treatment (Noble and Slayter 1980). In this study, root and basal sprouters (e.g., aspen and all shrubs except for sagebrush) and species with seeds requiring fire to stimulate germination (e.g., mountain balm [Ceanothus velutinus Dougl.], long-sepaled globe mallow [Iliamna longisepala \{Torr.\} Wiggins]) were the primary responders following fall fire. Species with growing points at or above the soil surface, particularly bunchgrasses (e.g., bearded wheatgrass [Agropyron caninum \{L.\} Beauv.], Idaho fescue [Festuca idahoensis Elmer], Sherman big bluegrass [Poa ampla Scribn.], Columbian needlegrass [Stipa columbiana Macoun]), and species that depend on reproduction by seed increased following the SPRING treatment, whereas in the FALL treatment they were reduced or eliminated.
Table 4. Herbaceous species richness $\times$ functional group for the three treatments. Means and standard errors are shown. Different lowercase letters indicate significant differences among the treatments $\times$ year for each response variable.

\begin{tabular}{lccr}
\hline Year and treatment & Perennial grasses & Perennial forbs & Annual forbs \\
\hline 2000 & & & \\
$\quad$ CONTROL & $7.0 \pm 0.9$ & $13.6 \pm 1.5 \mathrm{ab}$ & $8.0 \pm 1.7$ \\
FALL & $7.0 \pm 0.3$ & $12.2 \pm 1.0 \mathrm{a}$ & $8.4 \pm 1.4$ \\
SPRING & $7.8 \pm 0.5$ & $16.6 \pm 0.9 \mathrm{~b}$ & $6.3 \pm 1.0$ \\
2002 & & & \\
CONTROL & $7.8 \pm 1.0 \mathrm{a}$ & $17.0 \pm 2.3 \mathrm{~b}$ & $8.0 \pm 1.0 \mathrm{a}$ \\
FALL & $5.8 \pm 0.4 \mathrm{a}$ & $10.0 \pm 1.9 \mathrm{a}$ & $12.2 \pm 0.4 \mathrm{~b}$ \\
SPRING & $10.8 \pm 0.4 \mathrm{~b}$ & $25.0 \pm 0.8 \mathrm{C}$ & $7.0 \pm 0.9 \mathrm{a}$ \\
2003 & & & \\
CONTROL & $7.4 \pm 0.7 \mathrm{a}$ & $16.6 \pm 1.2 \mathrm{~b}$ & $9.2 \pm 2.0 \mathrm{a}$ \\
FALL & $5.6 \pm 0.5 \mathrm{a}$ & $10.2 \pm 1.2 \mathrm{a}$ & $14.0 \pm 1.0 \mathrm{~b}$ \\
SPRING & $11.0 \pm 0.3 \mathrm{~b}$ & $22.4 \pm 0.2 \mathrm{c}$ & $9.0 \pm 1.0 \mathrm{a}$ \\
2004 & & & \\
CONTROL & $7.8 \pm 0.7 \mathrm{a}$ & $17.4 \pm 1.3 \mathrm{~b}$ & $7.8 \pm 0.7 \mathrm{a}$ \\
FALL & $6.8 \pm 0.6 \mathrm{a}$ & $11.6 \pm 1.6 \mathrm{a}$ & $13.8 \pm 0.9 \mathrm{~b}$ \\
SPRING & $11.2 \pm 0.4 \mathrm{~b}$ & $30.2 \pm 1.7 \mathrm{c}$ & $9.4 \pm 0.4 \mathrm{a}$ \\
\hline
\end{tabular}

The rapid increases in aspen and/or understory cover and density following the FALL and SPRING treatments likely resulted from increased resource availability (light, water, and nutrients). Even during the dry years in 2002 and 2003 (Fig. 1), there were substantial increases in vegetation cover in the FALL and SPRING treatments (Figs. 5-7). Herbaceous perennials were observed to extend their active growing season by 6 to 8 weeks in the FALL and SPRING treatments compared with the CONTROL. Soil water and nutrient availability were not measured in this study, but elsewhere soil water and nitrogen availability have been shown to increase following juniper control by cutting (Everett and Sharrow 1985; Bates et al. 2000, 2002) and after burning in aspen woodland (Amacher et al. 2001).

\section{Juniper Removal and Aspen Response}

We accepted the study's hypothesis that the FALL treatment would be more effective at removing juniper and stimulating aspen recruitment than the SPRING treatment. To stimulate root suckering, it is recommended that a minimum of $80 \%-$ $90 \%$ of mature aspen stems be killed (Bartos and Mueggler 1980; Brown 1985). This level of mortality effectively interrupts apical dominance and stimulates aspen suckering (Farmer 1962; Schier 1973). In the FALL treatment, aspen mortality exceeded removal requirements, which likely contributed to the greater suckering response compared with the SPRING treatment. The effectiveness of the FALL treatment at removing juniper indicates that aspen will likely dominate the overstory the next $80-100$ years.

In the SPRING treatment, survival of $24 \%$ of adult aspen stems (and the bulk of the pretreatment suckers) and the presence of remaining adult juniper probably interfered with aspen suckering response. The SPRING treatment probably prolonged aspen site occupancy, but the lower suckering 


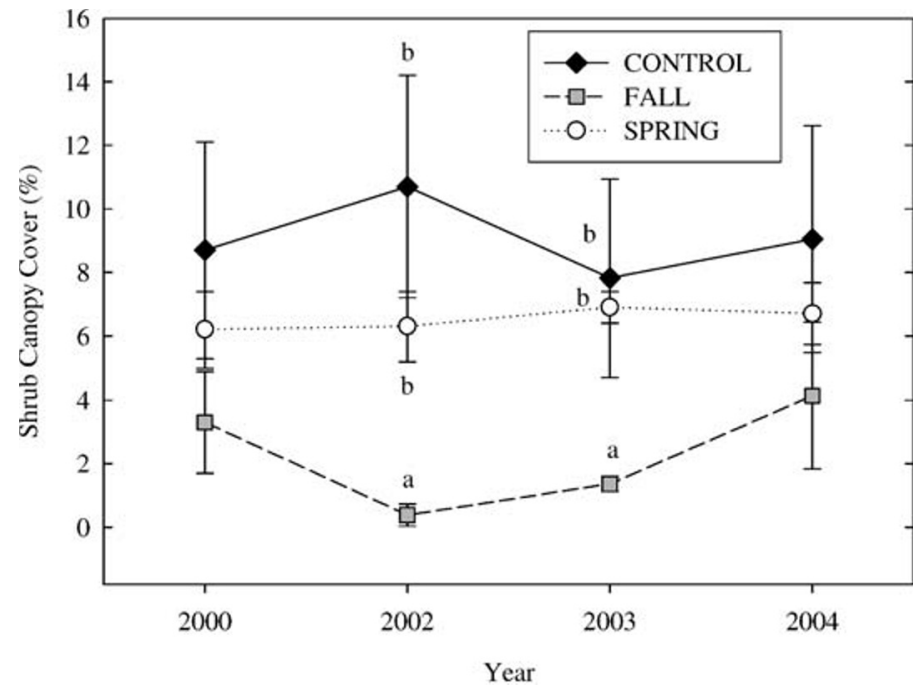

Figure 8. Shrub canopy cover (percent) among the three treatments from 2000 to 2004. Values represent means \pm 1 standard error. Different lowercase letters indicate significant differences $(P<0.05)$ among the treatments within year.

response and the presence of juniper will result in codominance of the overstory by aspen and juniper in the next 30 years, based on juniper invasion estimates from Wall et al. (2001).

Other environmental factors may also have contributed to the lower suckering response in the SPRING treatment. Full sunlight and higher soil temperatures are important for increasing cytokinin production in root meristems, which further stimulates aspen suckering response (Farmer 1963; Williams 1972; Schier et al. 1985). Increased herbaceous cover and maintenance of litter layers may have insulated soils and limited soil heating in the SPRING treatment.

The level of aspen response was lower than values reported elsewhere for aspen restoration. Burning or clear-cutting aspen stands has been reported to increase aspen suckering from 17000 to 150000 stems/ha (Patton and Avant 1970; Bartos 1979; Bartos and Mueggler 1981; Bartos and Mueggler 1982; Crouch 1983). These values are 1.5 to 30 times greater than stem densities reported for the FALL treatment. The lower suckering levels may be in response to the condition of aspen stands prior to treatment. Prior to treatment, aspen was scattered or confined to small portions of the study plots. After treatments were applied, aspen suckering was limited to areas in close proximity to fire-killed aspen trees. Aspen have the potential to colonize other areas within plots, given that these areas had at one time supported aspen prior to juniper encroachment.

Aspen response to treatment can be curtailed following disturbance when there is excessive browsing by wild ungulates (Bartos et al. 1994; Kay and Bartos 2000). Bartos and Mueggler (1980) suggested that prescribing larger burn areas may disperse animals across the landscape, thereby reducing heavy ungulate concentrations, and permitting aspen to re-establish successfully following fire. In our study, the lack of aspen browsing may have been a result of the BLM fire treatment, which was designed to treat a 2800 -ha area surrounding the aspen sites. Although elk and mule deer frequent the overall burn area, they rarely were observed to use the study sites. A factor in the successful regeneration and growth of aspen suckers in the FALL and SPRING treatments was the lack of browsing of aspen recruits.

\section{Ground Cover Dynamics}

Herbaceous response to the FALL treatment was slower and lower in magnitude than measured elsewhere following fall fire treatments in aspen. Bartos and Mueggler (1981) reported that herbaceous production peaked in the second and third year after a high-severity fire in aspen stands in northwestern Wyoming. Herbaceous cover in the FALL treatment did not reach full potential, and a sizeable area of bare ground remained open to further colonization (Fig. 6A). The response potential exhibited in the SPRING treatment, however, suggests that a continued increase in herbaceous cover may be expected in the FALL treatment. Herbaceous response to treatment in the SPRING treatment was similar in magnitude to results reported by Bartos and Mueggler (1982) after clear cutting aspen in Utah. They recorded a $250 \%$ increase in herbaceous productivity the first 3 years after cutting. In our study, herbaceous cover increased $330 \%$ by the third year after fire. Because herbaceous cover and species richness responded more rapidly, and was greater in the SPRING treatment compared with the FALL treatment, the study's second hypothesis was accepted.

\section{MANAGEMENT IMPLICATIONS}

The expansion of western juniper in the northern Great Basin has not only altered the structure and composition of plant communities, but is also influencing fuel characteristics and fire potentials. Aspen woodlands are difficult to burn because of the limited time period when fuel moisture conditions and weather are favorable (Jones and DeByle 1985b). As juniper occupies these communities, shrub and herbaceous layers that are necessary to carry fire through the stands are further reduced in cover and productivity (Miller et al. 2000). In this study, we demonstrated that partial cutting of juniper can increase the amount of cured surface fuels and allow prescribed fall fire to carry through decadent aspen stands, eliminate invading juniper, and stimulate aspen recruitment.

The study suggests that cutting one-third of overstory juniper will be adequate in providing the necessary cured fuels to eliminate remaining live junipers with fall fire in aspen woodlands that are dominated by western juniper. However, this was but one treatment scenario; the level of juniper encroachment into aspen stands varies across the Great Basin (Wall et al. 2001). Fuel loads will likely vary according to successional stage, location, and year. Thus, the level of juniper cutting necessary for fuel preparation may require adjustment in other areas. We are confident that this method of treatment can be applied to aspen woodlands being invaded by other conifer species in the western United States. Applying similar treatments elsewhere will require local understanding of fuel characteristics and testing different levels of cutting when combined with prescribed burning.

In the SPRING treatment, enough juniper seedlings and subcanopy trees were present to regain dominance in these stands in less than 80 years, based on successional estimates made by Miller and Bates (2001) and Wall et al. (2001). Increasing the 
level of cutting would increase the number of juvenile trees removed with spring fire. However, a sizable number would still survive the fire, given that complete surface coverage by downed juniper may not be achieved. Follow-up management by additional cutting or prescribed fire will be necessary to remove juniper that were missed in the initial treatment.

Spring burning may be useful in plant communities where the understory is depleted and managers desire a more rapid response to treatment of this vegetation layer. One advantage of spring burning is that the fire application can be more easily confined to the treatment area without risk of escape. This can be important, given that aspen stands in the Great Basin are often intermixed with sagebrush and riparian plant communities. It may be desirable to protect these areas, particularly sagebrush grassland, to avoid negative impacts to wildlife and other resource values.

In conclusion, if the management objective is to eliminate western juniper with minimal cutting and stimulate greater aspen suckering, then we recommend fall burning. If the objective is initially to increase herbaceous cover and composition and moderately increase aspen suckering, then spring burning is recommended.

\section{ACKNOWLEDGMENTS}

The authors are grateful to Otley Brothers, Inc, for generously providing logistical support. Many thanks are extended to the Bureau of Land Management, Burns Field Office, for providing land for conducting the research and in applying the treatments. Special thanks to Jim Buchanan, Range Conservationist, at the Burns BLM office for all his efforts. Finally, the success of the research project owes much to the many student summer range technicians who assisted in the collection of field data.

\section{LITERATURE CITED}

Amacher, M. C., D. L. Bartos, T. Christopherson, A. D. Johnson, and D. E. Kutterer. 2001. Nitrogen mineralization in the aspen/conifer soils after a natural fire. In W. D. Sheppard, D. Binkley, D. L. Bartos, T. J. Stohlgren, and L. G. Eskew [comps.]. Sustaining aspen in western landscapes. Symposium Proceedings; 13-15 June 2000; Grand Junction, CO. Proceedings RMRS-P-18. Fort Collins, CO: USDA-Forest Service, Rocky Mountain Research Station. p 415-426.

Bartos, D. L. 1979. Effects of burning on the aspen ecosystem. In: K. Johnson [ED.]. Wyoming shrublands. Proceedings of the Eighth Wyoming Shrub Ecology Workshop; 30-31 May 1979; Jackson, WY. Laramie: University of Wyoming. p 47-58.

Bartos, D. L., J. K. Brown, and G. D. Booth. 1994. Twelve years biomass response in aspen communities following fire. Journal of Range Management 47:79-83.

Bartos, D. L., and R. B. Campbell. 1998. Decline of quaking aspen in the interior west-examples from Utah. Rangelands 20:17-25.

Bartos, D. L., AND W. F. Mueggler. 1980. Influence of fire on vegetation production in the aspen ecosystem in western Wyoming. In: M. S. Boyce and L. D. Hayden-Wing [EDS.]. North American elk, ecology, behavior, and management. 2nd ed. Laramie: University of Wyoming Press. p 75-78.

Bartos, D. L., AND W. F. Mueggler. 1981. Early succession in aspen communities following fire in western Wyoming. Journal of Range Management 34 315-318.

Bartos, D. L., AND W. F. Mueggler. 1982. Early succession following clear cutting of aspen in northern Utah. Journal of Range Management 35:764-748.

Bates J., R. F. Miller, and T. S. Svescar. 2000. Understory dynamics in cut and uncut western juniper woodlands. Journal of Range Management 53: $119-126$.

Bates J., T. S. SVeJcAR, and R. F. Miller. 2002. Effects of juniper cutting on nitrogen mineralization. Journal of Arid Environments 51:221-234.

Bates J. D., T. SvejcaR, and R. F. Miller. 2004. Forage production in a cut juniper woodland. In: Range Field Day Report 2004: Current Forage and Livestock Production Research. Corvallis: Oregon State University Agricultural Experiment Station. Special Report 1052. p 24-32.

BRown, J. K. 1985. Fire effects and applications of prescribed fire in aspen. In: K. Sanders and J. Durham [EDS.]. Proceedings Rangeland Fire Effects: a symposium; 27-29 November 1984; Boise, ID. Boise, ID: United States Department of Interior Bureau of Land Management. p 38-47.

Crouch, G. L. 1983. Aspen regeneration after clearcutting in southwestern Colorado. Journal of Forestry 83:316-319.

DeByLE, N. V. 1980. Potential effects of stable versus fluctuating elk populations in the aspen ecosystem. In: M. S. Boyce and L. D. Hayden-Wing [EDS.]. North American elk, ecology, behavior, and management. 2nd ed. Laramie: University of Wyoming Press. p 13-19

DeByle, N. V. 1985. Animal impacts. In: N. V. DeByle and R. P. Winokur [eds.]. Aspen: ecology and management in the western United States. Fort Collins, CO: USDA, Forest Service, Rocky Mountain Forest and Range Experiment Station. General Technical Report RM-119. p 115-123.

Engle, D. A., AND T. G. Bidwell. 2001. The response of central North American prairies to seasonal fire. Journal of Range Management 54:2-10.

Everett, R. L., AND S. H. Sharrow. 1985. Soil water and temperature in harvested and non-harvested pinyon-juniper stands. Ogden, UT: Intermountain Research Station, USDA-Forest Service. Research Paper INT-342. 12 p.

Farmer, R. E. 1962. Aspen root sucker formation and apical dominance. Forest Science 8:403-410.

Farmer, R. E. 1963. Effect of light severity on growth of Populus tremuloides cuttings under two temperature regimes. Ecology 44:409-411.

GRUELL, G. E. 1979. Wildlife habitat investigations and management: implications on the Bridger-Teton National Forest. In: M. S. Boyce and L. D. Hayden-Wing [EDS.]. North American elk, ecology, behavior, and management. 2nd ed. Laramie: University of Wyoming Press. p 63-74.

Hitchoock, C. L., and A. Cronquist. 1987. Flora of the Pacific Northwest. 6th printing. Seattle: University of Washington Press. $710 \mathrm{p}$.

HowE, H. F. 2000. Grass response to seasonal burns in experimental plantings. Journal of Range Management 53:437-441.

Jones, J. R., And N. V. DeByle. 1985a. Climates. In: N. V. DeByle and R. P. Winokur [EDS.]. Aspen: ecology and management in the western United States. Fort Collins, CO: USDA-Forest Service, Rocky Mountain Forest and Range Experiment Station. General Technical Report RM-119. p 57-64.

Jones, J. R., and N. V. DeByle. 1985b. Fire. In: N. V. DeByle and R. P. Winokur [EDS.]. Aspen: ecology and management in the western United States. Fort Collins, CO: USDA-Forest Service, Rocky Mountain Forest and Range Experiment Station. General Technical Report RM-119. p 77-81.

KAY, C. E. 1995. Aboriginal overkill and native burning: implications for modern ecosystem management. Western Journal of Applied Forestry 10:121-126.

KAY, C. E., AND D. L. BARTOS. 2000. Ungulate herbivory on Utah aspen: assessment of long-term exclosures. Journal of Range Management 53:145-153.

Maser, C., J. W. Thomas, and R. G. Anderson. 1984. Wildlife habitats in managed rangelands-the Great basin of southeastern Oregon: the relationship of terrestrial vertebrates to plant communities. Portland, OR: USDA-Forest Service, Pacific Northwest Forest Experiment Station. General Technical Report PNW-172. $35 \mathrm{p}$.

Miller, R. F., AND J. Bates. 2001. Stand characteristics of western juniper in Kiger Canyon, Oregon. In: R. F. Miller and J. D. Bates [EDs.]. History, ecology, and management of western juniper woodlands and associated shrublands: 2000 annual report. Burns, OR: Eastern Oregon Agricultural Research Center. p 35-43.

Miller, R. F., J. D. Bates, T. J. Svejcar, F. B. Pierson, and L. E. Eddleman. 2005. Biology, ecology, and management of western juniper. Corvallis, OR: Oregon State University Agricultural Experiment Station Technical Bulletin 152. 77 p. 
Miller, R. F., And J. R. Rose. 1995. Historic expansion of Juniperus occidentalis in southeastern Oregon. Great Basin Naturalist 55:37-45.

Miller, R. F., T. J. Svescar, and J. R. Rose. 2000. Impacts of western juniper on plant community composition and structure. Journal of Range Management 53:574-585.

Noble, I. R., and R. 0. Slatyer. 1980. The use of vital attributes to predict successional changes in plant communities subject to recurrent disturbances. Vegetatio 43:5-21.

OLmsted, C. E. 1979. The ecology of aspen with reference to utilization by large herbivores in Rocky Mountain National Park. In: M. S. Boyce and L. D. Hayden-Wing [EDS.]. North American elk, ecology, behavior, and management. 2nd ed. Laramie: University of Wyoming Press. p 89-97.

Patton, D. R., and H. D. Avant. 1970. Fire stimulated aspen sprouting in a sprucefir forest in New Mexico. Fort Collins, C0: Rocky Mountain Forest and Range Experiment Station. USDA-Forest Service Research Note RM-159. 3 p.

Peterson, R. G. 1985. Design and analysis of experiments. New York, NY: Marcel Dekker. $429 \mathrm{p}$.

Pickett, S. T. A., AND P. S. White. 1985. Natural disturbance and patch dynamics: an introduction. In: S. T. A. Pickett and P. S. White [EDS.]. The ecology of natural disturbance and patch dynamics. San Diego, CA: Academic Press. p 3-13.
SAS [computer program]. 2002. User's guide. Release 8.03. Cary, NC: SAS Institute.

ScHIER, G. A. 1973. Seasonal production of cytokinin in sucker production from excised roots of Populus tremuloides and the role of endogenous auxin. Canadian Journal of Forest Science 3:459-461.

SCHIER, G. A. 1975. Deterioration of aspen clones in the middle Rocky Mountains. Ogden, UT: USDA-Forest Service, Intermountain Experiment Station. Research Paper INT-170. $14 \mathrm{p}$.

SCHieR, G. A., J. R. Jones, ANd R. P. WinokUR. 1985. Vegetative regeneration. In: N. V. DeByle and R. P. Winokur [EDS.]. Aspen: ecology and management in the western United States. Fort Collins, C0: USDA-Forest Service, Rocky Mountain Forest and Range Experiment Station. General Technical Report RM-119. p 29-34.

Sparks, J. C., M. W. Palmer, G. A., Bukendorf, R. E. Masters, and D. M. Engle. 1998. Effects of late growing-season and late dormant-season prescribed fire on herbaceous vegetation in restored pine-grassland communities. Journal of Vegetation Science 9:133-142.

Wall, T., R. F. MIller, and T. S. SveJcar. 2001. Juniper encroachment into aspen in the northwest Great Basin. Journal of Range Management 54:691-698.

Williams, K. R. 1972. The relationship of soil temperature and cytokinin production in aspen invasion [MS thesis]. Albuquerque: University of New Mexico. 39 p. 